\title{
How frequent are overactive bladder symptoms in women with urodynamic verification of an overactive bladder?
}

\section{Ürodinami ile aşır aktif mesane tanısı konmus kadınlarda aşır aktif mesane semptomları hangi sıklıkta bulunmaktadır?}

\author{
Ahmet Özgür Yeniel ${ }^{1}$, Mete Ahmet Ergenoğlu ${ }^{1}$, Reci Meseri ${ }^{2}$, Niyazi Aşkar ${ }^{1}$, Ísmail Mete İtil ${ }^{1}$ \\ 'Department of Gynecology and Obstetrics, Faculty of Medicine, Ege University, Izmir, Turkey \\ ${ }^{2}$ Department of Nutrition and Dietetics, Izmir Atatürk School of Health, Ege University, Izmir, Turkey
}

\section{Abstract}

Objective: To determine the relationship between overactive bladder symptoms and urodynamic verification of overactive bladder.

Material and Methods: Between June 2011 and November 2011, 159 patients underwent urodynamics (UDS) at our urogynecology unit in the Ege University Hospital. Of these, 95 patients who complained of urgency, did not have any overt neurological diseases, bladder outlet obstruction and did not take any medication affecting the lower urinary tract function were evaluated. SPSS (ver. 15.0) was used to evaluate the data and the chi-square test and $t$ test for independent samples were used for analysis.

Results: The mean age was found to be $54.5 \pm 12$. Frequency was the most frequent symptom in women with overactive bladder (OAB) (82.1\%), nocturia (57.8\%) and (57.8\%) urgency urinary incontinence followed in frequency. Detrusor over activity incidence was found to be $38.9 \%$. There was no significant relationship between the presence of detrusor over activity (DOA) and OAB symptoms. Leak at urodynamics was found in $46.3 \%$ and there is no significant association with detrusor overactivity. Total bladder capacity was found to be significantly lower in women who had DOA $(\mathrm{p}=0.000)$.

Conclusion: It appears that overactive bladder symptoms do not predict detrusor over activity. Urodynamic investigation is not mandatory in the initial management of women with only OAB symptoms.

(J Turkish-German Gynecol Assoc 2012; 13: 98-101)

Key words: Overactive bladder, urodyamics, urgency urinary incontinence, detrussor over activity

Received: 10 January, 2012

Accepted: 01 February, 2012
Özet

Amaç: Aşırı aktif mesane semptomları ile tanısı ürodinamik olarak doğrulanmış aşırı aktif mesane arasındaki ilişkinin belirlenmesi.

Gereç ve Yöntemler: Ege Üniversitesi Ürojinekoloji ünitesinde, Haziran 2011 ve Kasım 2011 tarihleri arasında ürodinami ile değerlendirilen 159 hasta sunulan çalışmaya dahil edilmiştir. Bu olguların 95'inde urgency yakınması bulunuyordu ve bu olgular da belirgin nörolojik hastalık, mesane çıkış obstrüksiyonu yada alt üriner sistemi etkileyebilecek ilaç kullanım öyküsü yoktu. İstatistiksel analizlerde ki-kare ve t-test SPSS (ver 15.0) ile kullanıldı.

Bulgular: Olguların ortalama yaşı $54.5 \pm 12$ bulundu. Aşırı aktif mesaneli kadınlarda idrara sık çıkma şikayeti (\%82.1) en sık saptanan yakınma iken noktüri (\%57.8) ve urgency üriner inkontinans (\%57.8) bunu takip eden yakınmalardır. Detrüsör aşıı aktivitesi (DAA) \%38.9 bulundu. Detrusor aşır aktivitesi (DAA) ile aşır aktif mesane (AAM) arasında anlamlı ilişki bulunmadı. Ürodinamik inkontinans \%46.3 bulundu ve DAA ile anlamlı ilişki saptanmadı. Total mesane kapasitesi DAA'lı olgularda anlamlı olarak daha düşük saptandı $(\mathrm{p}=0.000)$.

Sonuç: Aşırı aktif mesane semptomlarının detrusor aşırı aktivitesini öngörmüyor gibi gözükmektedir. Ürodinamik inceleme yanlızca aşırı aktif mesane semptomu olan kadınların başlangıç değerlendirmesinde gerekli değildir. (J Turkish-German Gynecol Assoc 2012; 13: 98-101)

Anahtar kelimeler: Aşırı aktif mesane, ürodinamik değerlendirme, urgency, üriner inkontinans, detrosor aşırı aktivitesi

Geliş Tarihi: 10 Ocak 2012

Kabul Tarihi: 01 Şubat 2012

ated by acetylcholine-induced stimulation of bladder muscarinic receptors (2). It has been reported that the rate of DOA in women who have OAB symptoms is $22-58.4 \%$ (3-5). Some studies reported that there is a significant relationship between DOA and frequency, nocturia and urgency urinary incontinence $(5,6)$. However, the association between the symptoms of OAB and DOA are still unclear in women with $\mathrm{OAB}$. There is no consensus about symptomatic diagnosis of OAB and DOA in women $(3,4,7,8)$. The aim of this study was to evaluate the relationship between OAB symptoms and an urodynamic diagnosis of detrusor over activity. tions are termed detrusor over activity (DOA) and are medi- 


\section{Material and Method}

\section{Sample Population}

Between June 2011 and November 2011, 159 patients underwent UDS at our urogynecology clinic in the Ege University Hospital. Of these, 95 patients who complained of urgency did not have any overt neurological, bladder outlet obstruction and did not take any medication affecting the lower urinary tract function were evaluated. We retrospectively scanned urogynecologic evaluation reports which have included urinary diary, patient socio-demographic characteristics, and urodynamics. The study obtained approval from the local ethics committees.

\section{Urogynecologic evaluation}

The routine urogynecological protocol was performed before urodynamic testing. This included a comprehensive urogynecologic history, pelvic examination, a 3-day urinary diary, and no urinary infection.

\section{Urogynecologic history}

It was included in the data on socio-demographic characteristics such as age, weight, height, smoking, parity, gravida, menopausal status, previous medication or surgery. Body mass index was calculated by weight $(\mathrm{kg}) /$ height $\left(\mathrm{m}^{2}\right)$. Obesity was defined as 30 or more BMI value.

Table 1. Participants' demographic characteristics

\section{Pelvic examination}

It consists of a cough stress test, residual volume measuring, Q-tip test, and POP-Q staging (9, 10).

\section{Urinary diary}

Frequency (eight voids per day), nocturia (two voids per night), and symptomatic incontinence (OAB wet; at least once a day or OAB dry, respectively) were determined.

\section{Urodynamics}

Urodynamics were performed in accordance with the criteria established by the International Continence Society (ICS) (11). The presence or absence of DOA and leakage during UDS were determined.

\section{Statistical Analysis}

SPSS vers 15.0 was used for evaluation of the data. Continuous variables were presented as means \pm SD and analyzed via the $\mathrm{t}$ test for independent samples. Classified variables were presented as $\mathrm{n}-\%$ tables and compared via the Yates corrected Chi-square test. $\mathrm{p}<0.05$ was considered as significant.

\section{Result}

Table 1 shows the demographic characteristics of women who were included in the present study. One hundred fifty

\begin{tabular}{|c|c|c|c|c|c|c|c|}
\hline & \multirow{2}{*}{\multicolumn{2}{|c|}{$\begin{array}{l}\text { All participants } \\
(n=95)\end{array}$}} & \multicolumn{4}{|c|}{ Detrusor Over Activity } & \multirow[t]{3}{*}{$* \mathbf{p}$} \\
\hline & & & \multicolumn{2}{|c|}{$\begin{array}{c}\text { Absent } \\
(n=58)\end{array}$} & \multicolumn{2}{|c|}{$\begin{array}{c}\text { Present } \\
(n=37)\end{array}$} & \\
\hline & Mean & SD & Mean & SD & Mean & SD & \\
\hline Age & 54.5 & 12.1 & 53.3 & 11.98 & 56.5 & 12.2 & NS \\
\hline Parity & 3.1 & 1.7 & 2.9 & 1.65 & 3.5 & 1.6 & NS \\
\hline Gravida & 4.3 & 2.2 & 4.0 & 2.19 & 4.7 & 2.3 & NS \\
\hline BMI & 29.2 & 4.3 & 29.0 & 4.52 & 29.7 & 3.9 & NS \\
\hline & $\mathbf{n}$ & $\%$ & $\mathbf{n}$ & $\%$ & $\mathbf{n}$ & $\%$ & $* * \mathrm{p}$ \\
\hline Menopause & & & & & & & NS \\
\hline yes & 33 & 34.7 & 38 & 61.3 & 24 & 38.7 & \\
\hline no & 62 & 65.3 & 20 & 60.6 & 13 & 39.4 & \\
\hline Prolapse & & & & & & & NS \\
\hline yes & 25 & 26.3 & 28 & 75.7 & 9 & 24.3 & \\
\hline no & 70 & 73.7 & 42 & 72.4 & 16 & 27.6 & \\
\hline Obesity & & & & & & & NS \\
\hline yes & 37 & 38.9 & 21 & 56.8 & 16 & 43.2 & \\
\hline no & 58 & 61.1 & 37 & 63.8 & 21 & 36.2 & \\
\hline Smoking & & & & & & & NS \\
\hline yes & 21 & 22.1 & 15 & 71.4 & 6 & 28.6 & \\
\hline no & 74 & 77.9 & 43 & 58.1 & 31 & 41.9 & \\
\hline
\end{tabular}


nine women who had attended our urogynecology unit were evaluated. 95 of these women (59.7\%) had urgency. These participants were described as an overactive bladder. In addition frequency, nocturia, urgency incontinence might be accompanying the urgency. DOA was found to be present in $38.9 \%$. There is no significant relationship between the presence of DOA and OAB symptoms. Table 2 shows the relationship between OAB symptoms and DOA. Table 3 shows the urodynamics findings. Leak at urodynamics was found in $46.3 \%$. Total bladder capacity was found significantly lower in women who had DOA.

\section{Discussion}

Epidemiological studies have reported the prevalence of OAB as $16-17 \%$, and this percentage increased to $21 \%$ for women older than 70 years $(12,13)$.

Symptoms of urinary frequency, nocturia, and urgency are common among adult women. Frequency, urgency, and urge incontinence alone or in combination form the basic group of symptoms of $\mathrm{OAB}(14,15)$. OAB is a common and distressing problem known to adversely affect the quality of life because of these symptoms (16).

Our study demonstrates that OAB symptoms do not overlap urodynamic verification of OAB. In the present study, total bladder capacity was found significantly lower in women with DOA as in a previous study (7). Although DOA was reported as a main factor for $\mathrm{OAB}$, it appears different underlying patho- physiologic factors play a role in women with OAB. Urgency is a pivot symptom, according to the OAB definition (1). Some studies reported a significant association between urgency and DOA (6-17).

However, Brummen et al. (5) reported a main association between frequency and DOA, while urgency was associated poorly with DOA. Hashim and Abrahams reported that urgency coexisting with urgency incontinence and frequency is a better predictor than frequency alone for DOA. On the other hand, 10 or more daytime micturition episodes in women with OAB was found to be associated with DOA $(4,8)$. According to studies which reported an association between OAB symptoms and DOA, urodynamic evaluation might be a part of the assessment in the management of women who had OAB symptoms. However, there is controversy about the association between OAB symptoms and urodynamic verification of DOA. Digesu et al. reported that there is no significant correlation between OAB symptoms and DOA. On the other hand, they detected that $72.4 \%$ women who had DOA did not have OAB symptoms and $20.8 \%$ of women with OAB symptoms had an urodynamic diagnosis of genuine stress incontinence (3). In conclusion, it appears that overactive bladder symptoms do not predict detrusor over activity. Although there is no sufficient medical data based on urodynamic investigations in women with $\mathrm{OAB}$, in the light of available data we suggested that urodynamic investigation is not mandatory in the initial management of women with only OAB symptoms.

Table 2. The relationship between OAB symptoms and DOA

\begin{tabular}{|c|c|c|c|c|c|}
\hline & \multicolumn{4}{|c|}{ Detrusor Over Activity } & \multirow[t]{3}{*}{$*^{*} \mathbf{p}$} \\
\hline & \multicolumn{2}{|c|}{ Absent } & \multicolumn{2}{|c|}{ Present } & \\
\hline & $\mathbf{n}$ & $\%$ & $\mathbf{n}$ & $\%$ & \\
\hline Nocturia & 33 & 56.9 & 22 & 59.5 & NS \\
\hline Urge incontinence & 32 & 55.2 & 23 & 62.2 & NS \\
\hline Frequency+Urge incontinence & 30 & 51.7 & 19 & 51.4 & NS \\
\hline Nocturia+Urge incontinence & 18 & 31 & 12 & 32.4 & NS \\
\hline Frequency+Nocturia+Urge incontinence & 18 & 31 & 12 & 32.4 & NS \\
\hline
\end{tabular}

Table 3. Urodynamics findings

\begin{tabular}{|c|c|c|c|c|c|}
\hline & \multicolumn{4}{|c|}{ Detrusor Over Activity } & \multirow[t]{3}{*}{$* \mathbf{p}$} \\
\hline & \multicolumn{2}{|c|}{ Absent } & \multicolumn{2}{|c|}{ Present } & \\
\hline & Mean & SD & Mean & SD & \\
\hline FD & 161.12 & 62.76 & 147.89 & 84.45 & NS \\
\hline \multirow[t]{2}{*}{ TBC } & 449.55 & 138.56 & 348.49 & 119.88 & 0.000 \\
\hline & $\mathbf{n}$ & $\%$ & $\mathbf{n}$ & $\%$ & $* * \mathbf{p}$ \\
\hline Leak at UDS & 25 & 43.1 & 19 & 51.4 & NS \\
\hline
\end{tabular}




\section{Conflict of interest}

No conflict of interest was declared by the authors.

\section{References}

1. Haylen BT, de Ridder D, Freeman RM, Swift SE, Berghmans B, Lee J, et al. An International Urogynecological Association (IUGA)/ International Continence Society (ICS) joint report on the terminology for female pelvic floor dysfunction. Neurourol Urodyn 2010; 29: 4-20.

2. Andersson KE, Arner A. Urinary bladder contraction and relaxation: physiology and pathophysiology. Physiol Rev 2004; 84: 935-86. [CrossRef]

3. Digesu GA, Khullar V, Cardozo L, Salvatore S. Overactive bladder syndromes: do we need urodynamics? Neurourol.Urodyn 2003; 22 : 105-8. [CrossRef]

4. Hashim $\mathrm{H}$, Abrams P. Is the bladder a reliable witness for predicting detrusor overactivity? J Urol 2006; 175: 191-4 [CrossRef]

5. Van Brummen HJ, Heintz APM, van der Vaart $\mathrm{CH}$. The association between overactive bladder symptoms and objective parameters from bladder diary and filling cystometry. Neurourol. Urodyn. 2004; 23: 38-42. [CrossRef]

6. Chung SD, Liao CH, Chen YC, Kuo HC. Urgency severity scale could predict urodynamic detrusor overactivity in patients with overactive bladder syndrome. Neurourol Urodyn 2011; 30: 7: 1300-4.

7. Guralnick ML, Grimsby G, Liss M, Szabo A, O'Connor RC. Objective differences between overactive bladder patients with and without urodynamically proven detrusor overactivity. Int Urogynecol $\mathrm{J}$. 2010; 21: 325-9. [CrossRef]

8. Hashim $\mathrm{H}, \mathrm{Abrams}$ P. Is the bladder a reliable witness for predicting detrusor overactivity? J Urol. 2006; 175: 191-4. [CrossRef]
9. Karram MM, Bhatia NN. The Q-tip test: standardization of the technique and its interpretation in women with urinary incontinence. Obstet Gynecol 1988; 71: 807-11.

10. Bump RC, Mattiasson A, Bo K, Brubaker LP, DeLancey JOL, Klarskov P, et al. The standardization of terminology of femal pelvic floor dysfunction. Am J Obstet Gynecol 1996; 175: 10-7. [CrossRef]

11. Abrams P, Cardoso L, Fall M, Griffiths D, Rosier P, Ulmsten U, et al. The standardisation of terminology of lower urinary tract function: report from the Standardisation Sub-committee of the International Continence Society. Am J Obstet Gynecol 2002; 187: 116-26. [CrossRef]

12. Stewart WF, Corey R, Herzog AR, et al. Prevalence of overactive bladder in women: results from the NOBLE program. Int Urogynaecol J 2001; 12: 66.

13. Milsom I, Abrams P, Cardozo L, Roberts RG, Thuroff J, Wein AJ. How widespread are the symptoms of overactive bladder and how are they managed? A population-based prevalence study. BJU Int 2001;87: 9: 760-6. [CrossRef]

14. Dwyer PL, Rosamilia A. Evaluation and diagnosis of the overactive bladder. ClinObstet Gynecol 2002; 451: 193-204. [CrossRef]

15. FitzGerald MP, Butler N, Shott S, Brubaker L. 2002. Bother arising from urinary frequency in women.NeurourolUrodyn 2002; 21: 36- 40. [CrossRef]

16. Coyne KS, Sexton CC, Vats V, Thompson C, Kopp ZS, Milsom I. National community prevalence of overactive bladder in the United States stratified by sex and age. Urology 2011; 77: 1081-7. [CrossRef]

17. Haylen BT, Chetty N, Logan V, Schulz S, Verity L, Law M, et al. Is sensory urgency part of the same spectrum of bladder dysfunction as detrusor overactivity? Int Urogynecol J Pelvic Floor Dysfunct 2007; 18: 123-8. [CrossRef] 